Article

\title{
Electrospun Fibres of Chitosan/PVP for the Effective Chemotherapeutic Drug Delivery of 5-Fluorouracil
}

\author{
Jamie J. Grant ${ }^{1,2}$, Suresh C. Pillai ${ }^{1,2}{ }^{1}$, Tatiana S. Perova ${ }^{3, * \mathbb{D}}$, Sarah Hehir ${ }^{1,2}$, Steven J. Hinder ${ }^{4}$, \\ Marion McAfee ${ }^{2}\left(\mathbb{D}\right.$ and Ailish Breen ${ }^{1,2}$ \\ 1 Nanotechnology \& Bioengineering Division, Institute of Technology Sligo, Ash Lane, F91 YW50 Sligo, Ireland \\ James.Grant2@mail.itsligo.ie (J.J.G.); pillai.suresh@itsligo.ie (S.C.P.); hehir.sarah@itsligo.ie (S.H.); \\ breen.ailish@itsligo.ie (A.B.) \\ 2 Centre for Precision Engineering, Materials and Manufacturing Research (PEM Centre), Institute of \\ Technology Sligo, Ash Lane, F91 YW50 Sligo, Ireland; mcafee.marion@itsligo.ie \\ 3 Department of Electronic and Electrical Engineering, Trinity College Dublin, College Green, 2 Dublin, Ireland \\ 4 The Surface Analysis Laboratory, University of Surrey, Stag Hill, Guildford, Surrey GU2 7XH, UK; \\ s.hinder@surrey.ac.uk \\ * Correspondence: perovat@tcd.ie
}

Citation: Grant, J.J.; Pillai, S.C.; Perova, T.S.; Hehir, S.; Hinder, S.J.; McAfee, M.; Breen, A. Electrospun Fibres of Chitosan/PVP for the Effective Chemotherapeutic Drug Delivery of 5-Fluorouracil. Chemosensors 2021, 9, 70. https:/ / doi.org/10.3390/chemosensors 9040070

Academic Editor: Pi-Guey Su

Received: 8 February 2021

Accepted: 26 March 2021

Published: 31 March 2021

Publisher's Note: MDPI stays neutral with regard to jurisdictional claims in published maps and institutional affiliations.

Copyright: (c) 2021 by the authors. Licensee MDPI, Basel, Switzerland. This article is an open access article distributed under the terms and conditions of the Creative Commons Attribution (CC BY) license (https:// creativecommons.org/licenses/by/ $4.0 /)$.

\begin{abstract}
Electrospun nanofibrous mats consisting of chitosan (CS) and polyvinylpyrrolidone (PVP) were constructed. Tuning of solution and process parameters was performed and resulted in an electrospun system containing a 6:4 ratio of PVP:CS. This is a significant increase in the proportion of spun CS on the previously reported highest ratio PVP:CS blend. SEM analysis showed that the nanofibrous mats with $4 \mathrm{wt} \% \mathrm{CS} / 6 \mathrm{wt} \%$ PVP (sample E) comprised homogenous, uniform fibres with an average diameter of $0.569 \mu \mathrm{m}$. XPS analysis showed that the surface of the samples consisted of PVP. Raman and FTIR analysis revealed intermolecular interactions (via H-bonding) between PVP and CS. In FTIR spectra, the contribution of chitosan to CS/PVP complexes was shown by the downshift of the $\mathrm{C}=\mathrm{O}$ band and by the linear increase in intensity of $\mathrm{C}-\mathrm{O}$ stretching in CS. XPS analysis showed a smaller shift at the binding energy $531 \mathrm{eV}$, which relates to the amide of the acetylated functional groups. The obtained results demonstrate a sensitivity of Raman and FTIR tests to the presence of chitosan in PVP:CS blend. The chemotherapy drug 5-Fu was incorporated into the constructs and cell viability studies were performed. WST-8 viability assay showed that exposure of A549 human alveolar basal epithelial cells to $10 \mathrm{mg} / \mathrm{mL}$ 5-Fu loaded fibres was most effective at killing cells over $24 \mathrm{~h}$. On the other hand, the constructs with loading of $1 \mathrm{mg} / \mathrm{mL}$ of drug were not efficient at killing A549 human alveolar basal epithelial cells. This study showed that CS/PVP/5-Fu constructs have potential in chemotherapeutic drug delivery systems.
\end{abstract}

Keywords: chitosan; PVP; electrospinning; nanofibers; XPS; Raman; FTIR; cell viability; 5-Fluorouracil

\section{Introduction}

With advances in nanotechnology, substantial research is focused on the properties of nanoscale materials. Electrospinning is a technique which is widely used to manufacture nanofibers. Nanofibrous scaffolds have several applications ranging from filtration to biomedical applications. Electrospun fibres and scaffolds are finding their place as emerging devices in the delivery of cancer therapeutics [1,2]. The efficiency of electrospun fibres can be attributed to their large surface area to volume ratio characteristics and their 3-dimensional open porous system, the properties of which allow for high levels of drug loading and enhanced drug diffusion over time [3-5].

Chitosan (CS) is a widely studied natural polysaccharide because of its inherent non-toxicity, biocompatibility and biodegradability, and thus has been used in numerous biomedical applications including drug delivery [6]. While electrospinning of CS is commonly reported, it is notoriously difficult to electrospin and process in its pristine form. A 
common strategy used to overcome the challenges associated with chitosan is blending with a second polymer. The second polymer acts as an attenuating factor to limit the hydrogen bonds between chitosan chains, thus making the electrospinning of the polymer mixture possible $[7,8]$.

Polyvinylpyrrolidone (PVP) is an FDA-approved, synthetic, water-soluble polymer, commonly used to make electrospun fibres [9]. There have been several reports investigating the combination of chitosan and PVP for various applications [10,11]. Due to the difficulties involved with the spinning of chitosan, it is important that a common solvent is used for both chitosan and PVP.

The compatibility and miscibility of blends of chitosan/PVP has been previously examined and conclusions were made that chitosan and PVP were immiscible in various concentrations of aqueous acetic acid. Viscometry methods showed that the interactions between chitosan and PVP were too small for miscibility predictions due to both polymers' high affinity for solution [12].

Another study used an elevated-temperature electrospinning technique to form nanofibres of chitosan and PVP. A combination of "top-down" electrospinning and "bottom-up" molecular self-assembly was developed for preparing chitosan nanoparticles. Chitosan and PVP were spun together at $50 \pm 2{ }^{\circ} \mathrm{C}$. Characterization techniques were used to show that chitosan and PVP were mixed on a molecular scale. IR spectra showed that secondorder hydrogen bonding and electrostatic interactions played a large role in promoting homogeneity [13].

It has been shown that toxic solvents can be eliminated from electrospun chitosan systems by careful tuning of the solution parameters through the use of hydrolysing techniques to reduce the molecular weight of chitosan [14]. The concentration of acetic acid was reduced from $90 \%$ to $70 \%$ in comparison to other previous research $[15,16]$ while the molecular weight of electrospun chitosan was increased. Tuning the electrospinning solution parameters is critical to achieving a robust process and consistent electrospun fibres.

Chitosan has also been used to deliver and release the chemotherapy drug 5-Fluorouracil (5-Fu) to targeted carcinoma cells both in vitro and in vivo [17]. In one study, 5-Fu was electrospun with chitosan and polycaprolactone to analyse drug release [18]. Tests here showed that nanofibres containing more CS had a more efficient, prolonged drug release compared to other mat compositions. Another study showed the effect electrospun CS/PVA/5-Fu mats had on skin cancer cells [19]. Here, a controlled release mechanism was observed over $24 \mathrm{~h}$. The drug-loaded constructs were shown to decrease cell viability up to $\geq 50 \%$ over $24 \mathrm{~h}$. The researchers highlighted the potential for this system in drug delivery to target Basal Cell Carcinoma (BCC) skin cancer.

To date, there has not been a systematic investigation into the room-temperature electrospinning of high-ratio Chitosan/PVP blends for the development of an anti-cancer drug delivery vehicle. The aim of this research is to create an ambient temperature electrospinning protocol for the polymer system and to examine the effect electrospinning has on the chitosan and PVP blends. With this, the electrospun constructs will be examined for their potential use in releasing 5-fluorouracil to target human lung carcinoma cells in vitro.

\section{Materials and Methods}

\subsection{Materials}

Low-molecular weight chitosan (mol wt 50,000-190,000) (75-85\% deacetylated), trifluoracetic acid, TFA (99\%) and glacial acetic acid ( $\geq 99.85 \%)$ was purchased from Sigma Aldrich. High-molecular weight PVP (mol wt 1,300,000) was purchased from VWR. Ham's F-12 medium, penicillin-streptomycin solution and trypsin (pure from beef pancreas) were purchased from Fisher Scientific. Phosphate buffer saline (ultra-pure grade), Fetal Bovine Serum (Ireland Origin) and WST-8 Cell Proliferation Assay Kit were purchased from VWR. 


\subsection{Preliminary Analysis/Solubility Testing}

Initial tests were performed to examine the solubility of chitosan. Electrospinning of chitosan was unachievable using pure TFA. Glacial acetic acid was then introduced to the system in a 9:1 ratio which saw the production of fibres (see Table S1). The parameters that were altered were chitosan concentration, solvent and solvent concentration. Low-, medium- and high-molecular weight chitosan was investigated for its processability. The use of hydrolysed chitosan was also investigated. Briefly, $1 \mathrm{~g}$ of low molecular weight chitosan was added to $12.5 \mathrm{~g}$ of sodium hydroxide and $25 \mathrm{~mL}$ of water. This was heated to $95{ }^{\circ} \mathrm{C}$ for $48 \mathrm{~h}$. After this, the chitosan was filtered off. The collected chitosan was subsequently washed with water, neutralized with acetic acid, rinsed again with water and then finally dried for $16 \mathrm{~h}$ at $16^{\circ} \mathrm{C}$. A range of solutions of different hydrolysed chitosan concentrations was made up in $90 \%$ acetic acid.

\subsection{Chitosan-PVP Solutions}

To create chitosan-PVP solutions, $6 \mathrm{wt} \%$ PVP was dissolved in TFA:acetic acid in a 9:1 ratio. This was stirred at room temperature for $3 \mathrm{~h}$. Several solutions were made using $6 \mathrm{wt} \%$ PVP and chitosan in 9:1 TFA:glacial acetic acid. The concentrations of chitosan in solution were as follows: $0 \%, 1 \%, 2 \%, 3 \%, 4 \%$. These solutions were stirred for $8 \mathrm{~h}$ at room temperature to ensure full homogeneity. The samples were labelled from A through to $\mathrm{E}$, with A containing $0 \%$ CS 6\% PVP, B containing 1\% CS 6\% PVP, C containing $2 \%$ CS $6 \%$ PVP, D containing 3\% CS 6\% PVP and E containing 4\% CS 6\% PVP (Table S1).

\section{Chitosan-PVP-5-Fu Solutions}

New $4 \mathrm{wt} \% \mathrm{CS} / 6 \mathrm{wt} \%$ PVP solutions were developed using the solvent system as above. 5-Fu was added to make three separate solutions in total. These were $1 \mathrm{mg} / \mathrm{mL}$, $5 \mathrm{mg} / \mathrm{mL}$ and $10 \mathrm{mg} / \mathrm{mL}$ of drug in each CS/PVP solution.

\subsection{Electrospinning Procedure}

Each sample was loaded into a $5 \mathrm{~mL}$ syringe. This was then attached to the SprayBase ${ }^{\circledR}$ pump system. Luer Lock tubing was connected to the end of the syringe. The other end of the tubing was connected to an 18-gauge needle, which was held in place on the SprayBase ${ }^{\circledR}$ electrospinning system. The voltage was set at $15 \mathrm{kV}$, while the tip-collector gap was set at $15 \mathrm{~cm}$. A flow rate of $0.1 \mathrm{~mL} \mathrm{~h}^{-1}$ was used to collect the electrospun fibres. The fibres were collected for three hours on aluminium foil on a flat plate collector. The fibres were then dried at $123^{\circ} \mathrm{C}$ for $18 \mathrm{~h}$ in an oven.

\subsection{Characterization}

Each CS/PVP sample was removed from their aluminium foil and stored in air-tight tubes. Zeiss Gemini Ultra was used to perform Scanning Electron Microscopy (SEM) on each sample. ImageJ software was used to perform fibre diameter measurements, where 30 random fibres of each sample were measured. XPS analyses were performed on a ThermoFisher Scientific Instruments (East Grinstead, UK) K-Alpha+ spectrometer. XPS spectra were acquired using a monochromated $\mathrm{Al} \mathrm{K} \alpha \mathrm{X}$-ray source $(\mathrm{h} v=1486.6 \mathrm{eV})$. An $\mathrm{X}$-ray spot of $\sim 400 \mu \mathrm{m}$ radius was employed. Survey spectra were acquired employing a Pass Energy of $200 \mathrm{eV}$. High resolution, core level spectra for all elements were acquired with a Pass Energy of $50 \mathrm{eV}$. All high-resolution spectra were charge referenced against the $\mathrm{C} 1 \mathrm{~s}$ peak at $285 \mathrm{eV}$ to correct for charging effects during acquisition. Quantitative surface chemical analyses were calculated from the high resolution, core level spectra following the removal of a non-linear (Shirley) background. The manufacturers Avantage software (Thermo Fisher Scientific, Waltham, MA, USA) was used which incorporates the appropriate sensitivity factors and corrects for the electron energy analyser transmission function. Raman measurements were carried out in backscattering geometry using a Renishaw 1000 micro-Raman system with motorized positional stage and Leica microscope. A He-Ne laser at wavelengths of $633 \mathrm{~nm}$ at a power of $<10 \mathrm{~mW}$ (at the laser output) was 
used as the excitation source. The power was kept low to prevent the sample overheating. To reduce power further, laser filters were used with $50 \%$ of transmittance from the original laser power. The laser spot was focused on the sample surface (deposited onto cleaned Silicon wafer) using $50 \times$ magnification objectives with a long focus working distance. Since the angle of the scattering light cone with this objective is smaller than one obtained with short focus working distance objectives, the registered spectra even at a long time of signal accumulation (400 s) were relatively weak. Additionally, to register any spectrum reliably, it was necessary to focus the laser light on a single fibre and this resulted in low spectral intensity. Finally, Shimadzu IRAfinnity-1S was used to perform Fourier Transform Infrared Spectroscopy (FTIR) analyses using MIRacle 10 Single Reflection Attenuated Total Reflection (ATR) Accessory. The instrument was set at 100 runs to collect spectra in the region of $900-3900 \mathrm{~cm}^{-1}$ and $900-1900 \mathrm{~cm}^{-1}$.

\subsection{Cell Culture}

A549 cells were cultured with Ham's F-12 medium containing 10\% fetal bovine serum and $1 \%$ penicillin: streptomycin at $37^{\circ} \mathrm{C}$ with an atmosphere of $95 \%$ air and $5 \% \mathrm{CO}_{2}$. Cells in the logarithmic stage of growth were used for analysis.

\section{Cell Viability Assay}

Cell viability was determined using a Water-Soluble Tetrazolium- 8 (WST-8) assay. Cells were seeded in a 96-well flat-bottomed plate at a density of $8 \times 10^{4}$ cells $/ \mathrm{mL}$ with $100 \mu \mathrm{L}$ per well. They were then incubated for $24 \mathrm{~h}$ and following this, exposed to electrospun constructs for an additional $24 \mathrm{~h}$. After treatment, all media was removed from the cells. $100 \mu \mathrm{L}$ of fresh media was added to the wells along with $10 \mu \mathrm{L}$ of the WST-8 reagent. The plate was then incubated for two hours at $37^{\circ} \mathrm{C}$ in a $5 \% \mathrm{CO}_{2}$ incubator. The plate was read at $465 \mathrm{~nm}$ using a microtiter plate reader. At least three replicates were performed for each test.

\section{Results and Discussion}

\subsection{Electrospinning of Chitosan/PVP}

Both solution and process parameters play a vital role in achieving the electrospinning of any polymer. Blend electrospinning is a common way of combining two polymers with desirable characteristics and a facile way of incorporating therapeutics into the resultant systems.

Prior to the preparation of blends, an initial investigation of set system parameters was performed. Electrospinning of PVP alone at a concentration of $6 \%$ with process parameters of $15 \mathrm{kV}$ voltage, $15 \mathrm{~cm}$ tip collector gap and a flow rate of $0.1 \mathrm{~mL} / \mathrm{h}$ resulted in PVP fibres which were homogenous with good morphology. Chitosan was then systematically introduced into the blend and each Chitosan/PVP blend was electrospun keeping the initial process parameters consistent (Table S1).

\subsubsection{Tuning of Chitosan/PVP Blend Solution Parameters}

A series of blends of PVP and chitosan were electrospun in a solvent system of TFA and Acetic Acid in the ratio of 9:1. The polymer concentrations were as follows: (A) $0 \%$ chitosan $6 \%$ PVP, (B) $1 \%$ chitosan $6 \%$ PVP, (C) $2 \%$ chitosan $6 \%$ PVP, (D) $3 \%$ chitosan $6 \%$ PVP and (E) $4 \%$ chitosan $6 \%$ PVP. While fibre formation could be achieved based on these PVP and chitosan concentrations, instrument parameters were next investigated and refined accordingly to produce a stable ejection of fibres from the electrospinner (Table S2).

\subsubsection{Investigation of the Electrospinning Process Parameters on Fibres}

Good-quality fibres were produced by setting the voltage to $15 \mathrm{kV}$, tip-collector gap to $15 \mathrm{~cm}$ and flow rate to $0.1 \mathrm{~mL} / \mathrm{h}^{-1}$, which resulted in a steady/stable jet ejection being emitted from the Taylor Cone located at the needle tip. PVP concentration could not be raised above $6 \%$, while the chitosan concentration could not be raised above $4 \%$ since fibres 
were not formed when concentrations were raised above these values. It was necessary to use low molecular weight chitosan (mol. wt. 50,000-190,000) to eliminate the possibility of the solution becoming gel-like. The solvent system best suited was deemed to be TFA and acetic acid in a 9:1 ratio. It was necessary to set voltage at $15 \mathrm{kV}$; any higher distorted the Taylor Cone and any lower removed the Tylor Cone completely. The tip-collector gap was set at $15 \mathrm{~cm}$ while the flow rate was set at $0.1 \mathrm{~mL} / \mathrm{h}^{-1}$. This is a very slow flow rate which is important for the formation of chitosan/PVP fibres. A faster flow rate, as seen above, produces droplets from the Taylor Cone. It is also worth noting that the effect of temperature and humidity was initially studied and there were no significant changes to the spinnability of the polymers in our room-temperature setup.

\subsection{Characterization of Electrospun Blends}

Characterization of the CS/PVP fibres resulting from the electrospun blends was carried out by SEM, XPS, Raman and FTIR spectroscopy.

\subsubsection{SEM Analysis}

Each fibrous scaffold (A, B, C, D and E) was sputter-coated and analysed using scanning electron microscopy. Images were obtained for magnifications at $5 \mathrm{~K}$ (see Figure 1 ).
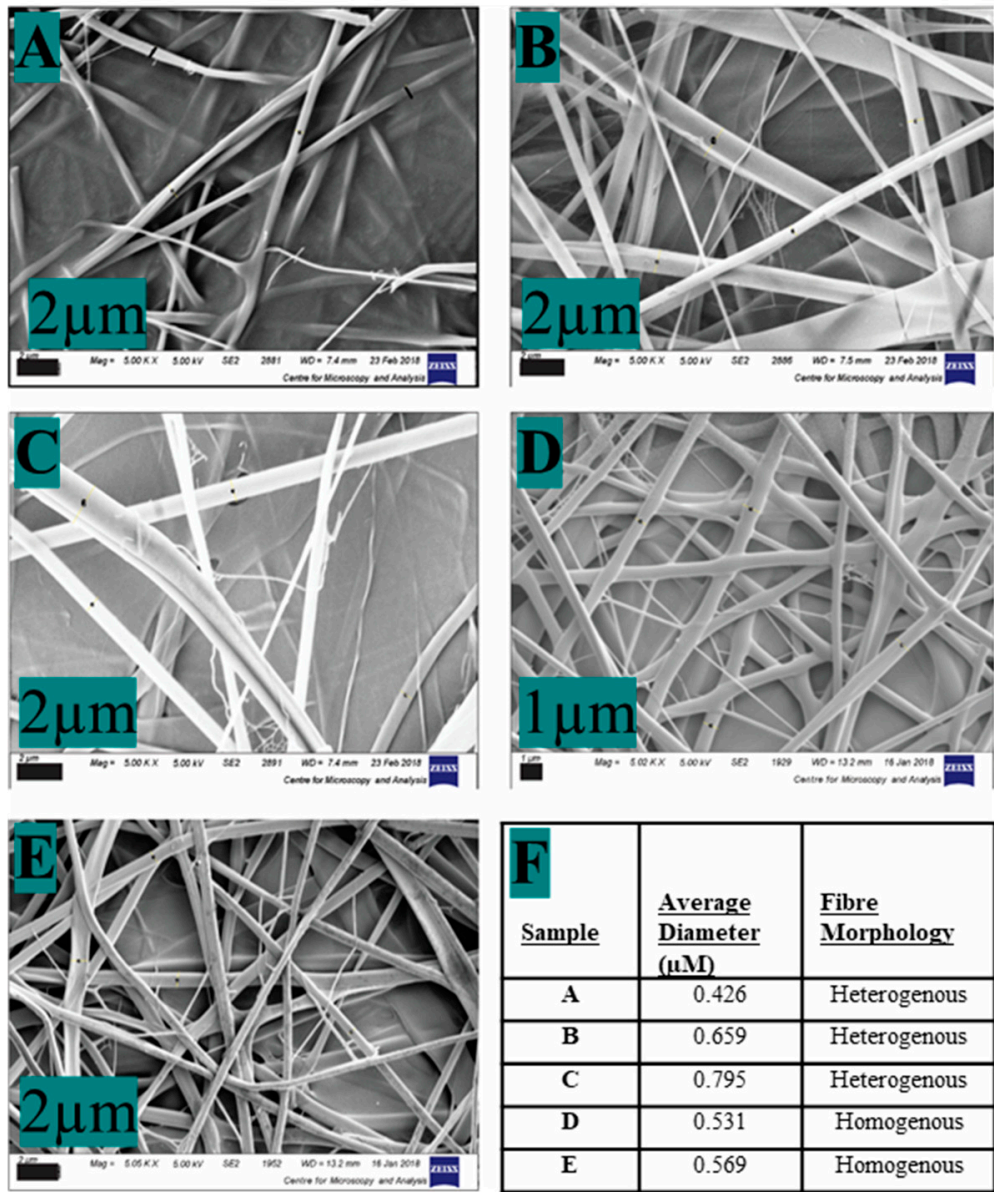

\begin{tabular}{|c|c|c|}
\hline Sample & $\begin{array}{l}\frac{\text { Average }}{\text { Diameter }} \\
\text { (uM) }\end{array}$ & $\begin{array}{l}\text { Fibre } \\
\text { Morphology }\end{array}$ \\
\hline $\bar{A}$ & 0.426 & Heterogenous \\
\hline $\bar{B}$ & 0.659 & Heterogenous \\
\hline $\mathrm{C}$ & 0.795 & Heterogenous \\
\hline$\overline{\mathbf{D}}$ & 0.531 & Homogenous \\
\hline $\bar{E}$ & 0.569 & Homogenous \\
\hline
\end{tabular}

Figure 1. SEM images under $5 \mathrm{~K}$ magnification for samples (A): mean fibre diameter \pm standard deviation $(\mu \mathrm{M})=0.426 \pm 0.115(B)$ : mean fibre diameter \pm standard deviation (SD) $(\mu \mathrm{M})=0.659 \pm 0.437(\mathrm{C})$ : mean fibre diameter $\pm \mathrm{SD}(\mu \mathrm{M})=0.795 \pm 0.416(\mathrm{D})$ : mean fibre diameter $\pm \mathrm{SD}(\mu \mathrm{M})=0.531 \pm 0.205(\mathrm{E})$ : mean fibre diameter $\pm \mathrm{SD}(\mu \mathrm{M})=0.569 \pm 0.219, n=30$ and $(\mathbf{F})$ summary of average diameter and morphology of each sample.

The mean fibre diameter for sample A ( $6 \%$ PVP, $0 \%$ chitosan) was found to be $0.426 \mu \mathrm{m}$ (SD of 0.115 ) after taking measurements of 30 random fibres. The mean fibre diameter is 
low since there is only PVP present. In theory, it is expected that the lowest concentration of polymer would produce the smallest diameter fibres, as is the case here. As shown by Yuya et al. [20], electrospinning of PVP with various concentrations leads to different fibre diameters. The article describes electrospinning PVP at $8 \%, 10 \%$ and $12 \% \mathrm{PVP}$, resulting in an average fibre diameter of $0.7,0.9$ and $1.2 \mu \mathrm{m}$, respectively. The mean diameter here of $0.426 \mu \mathrm{m}$, for sample A (6\% PVP), may correlate with their analysis, which may mean that PVP alone is present in this sample. The highest concentration of polymer often suggests the highest average fibre diameter [21], however this is not the case here. The previous literature has suggested a non-linear relationship between solution concentration and fibre diameter [22]. This may be due to a lack of beading and heterogeneities present in samples $\mathrm{D}$ and $\mathrm{E}$, thus presenting a narrower and smoother fibre.

\subsubsection{XPS Analysis}

XPS analysis gave a thorough indication of the surface composition of the fibrous composites along with the atomic percentage composition and electron configuration of the specified electrons within the atom. Each scaffold presented mainly $C 1 s, N$ s and $O$ 1 s characteristics (see Table 1). With regard to $C$ 1s, $N$ 1s and $O$ 1s, there were no major chemical shifts that indicate the presence of CS on the surface of the materials. There are a couple of reasons why it was difficult to establish the presence of CS. CS is used in a smaller minority in the blend compared to PVP, with the highest being $4 \% \mathrm{CS}$, compared to that of $6 \%$ PVP. Additionally, in terms of the molecular weights used, PVP had a molecular weight of 1,300,000. This is a factor of 6.84 to 26 times higher in comparison to that of chitosan (mol wt 50,000-190,000). It may be possible that the surface of the fibrous composites is deficient in CS. Additionally, in terms of the XPS analysis, the ketone functional group $(\mathrm{C}=\mathrm{O})$ in PVP may be masking the polysaccharide backbone oxygen in chitosan. In addition, $\mathrm{N}-\mathrm{C}=\mathrm{O}$ groups in PVP may be masking the non-protonated amine or amide contained within chitosan, which one would expect to see at approximately $399.3 \mathrm{eV}$ [23].

Table 1. XPS analysis showing the elemental composition of samples A-E.

\begin{tabular}{cccccc}
\hline & \multicolumn{5}{c}{ Sample (\%) } \\
\cline { 2 - 6 } Element & $\mathbf{A}$ & $\mathbf{B}$ & $\mathbf{C}$ & $\mathbf{D}$ & $\mathbf{E}$ \\
\cline { 2 - 6 } C 1s & 67.75 & 72.02 & 71.60 & 71.33 & 71.98 \\
N 1s & 6.17 & 9.44 & 9.28 & 8.55 & 8.31 \\
O 1s & 19.99 & 15.41 & 16.38 & 17.86 & 17.91 \\
F 1s & 0 & 2.22 & 2.11 & 0 & 0 \\
\hline
\end{tabular}

Samples B and C contained $2.22 \%$ and $2.11 \%$, respectively, of F 1s (see Figure 2). The reason for this was due to residual of TFA molecules on the fibres. As the concentration of chitosan increases from $1 \%$ through to $4 \%$, there were no significant chemical shifts regarding the $\mathrm{C}-\mathrm{C}$ or $\mathrm{C}=\mathrm{O}$ bonds (see Figure 2). This means it is difficult to highlight the presence of chitosan within the sample. 

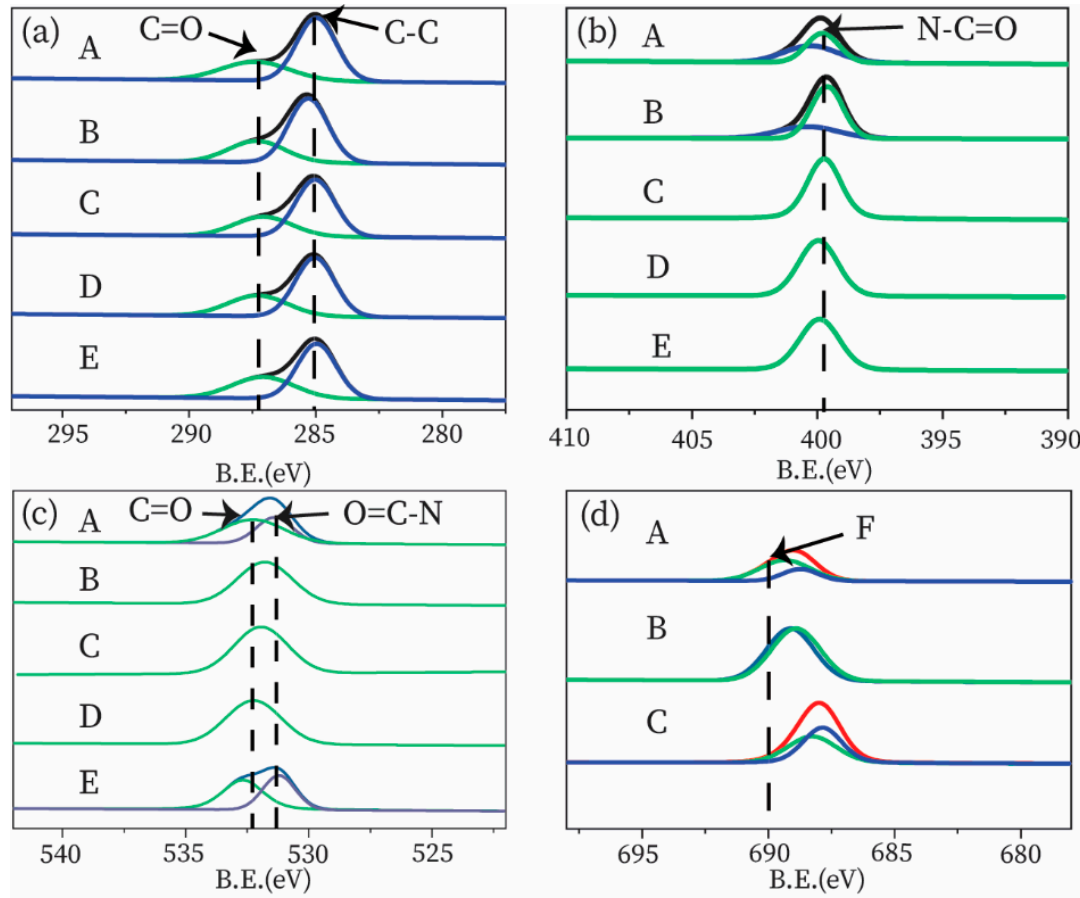

Figure 2. (a) The $C$ 1s spectra of samples: $A, B, C, D$ and $E$, (b) the $N$ 1s spectra of samples $A, B, C, D$ and E, (c) the O 1s spectra of samples A, B, C, D and E and (d) F 1s of samples A.B and C.

At approximately $531 \mathrm{eV}$, it is possible to see the presence of $\mathrm{N}-\mathrm{C}=\mathrm{O}$ groups within only sample A and E, which are $0 \%$ CS and $4 \%$ CS, respectively. These relate to the amide carbonyl group found within PVP. There were no significant chemical shifts regarding the $\mathrm{C}=\mathrm{O}$ and $\mathrm{N}-\mathrm{C}=\mathrm{O}$ groups as the concentration of chitosan increased from $0 \%$ to $4 \%$. Previous literature stated that the oxygen of the polysaccharide backbone in chitosan should be located at approximately $532.7 \mathrm{eV}$ [23]. Additionally, a smaller shift was seen at $531 \mathrm{eV}$, which relates to the amide of the acetylated functional groups. While XPS proved beneficial in analysing the surface composition of each fibrous scaffold, it was difficult to pinpoint the exact location of chitosan.

\subsubsection{Raman Analysis}

Raman spectra registered in the region $300-1750 \mathrm{~cm}^{-1}$ of samples A-E with different CS content are shown in Figure 3a. The spectra were baselined, normalised to the intensity of the band at $\sim 1670 \mathrm{~cm}^{-1}$ and then shifted along the $Y$-axis for convenience of presentation. From first glance, all spectra shown in Figure 3a demonstrate vibrational bands typical for PVP fibres (compare with the spectrum labelled as $0 \%$ ) with the following major bands assignment: ring C-C vibration at $753 \mathrm{~cm}^{-1}, \mathrm{C}-\mathrm{C}$ vibrations at $850 \mathrm{~cm}^{-1}, \mathrm{C}-\mathrm{C}$ ring breathing at $934 \mathrm{~cm}^{-1}, \mathrm{C}-\mathrm{C}$ - backbone at $1023 \mathrm{~cm}^{-1}, \mathrm{CH}$ deformation at $1372 \mathrm{~cm}^{-1}, \mathrm{CH}_{2}$ scissoring at $1495 \mathrm{~cm}^{-1}$ and amide carbonyl $(\mathrm{C}=\mathrm{O})$ stretching vibrations at $\sim 1670 \mathrm{~cm}^{-1}$ [24-27]. Similar band positions were observed earlier in different papers devoted to Raman study of complex PVP fibres [28,29]. 

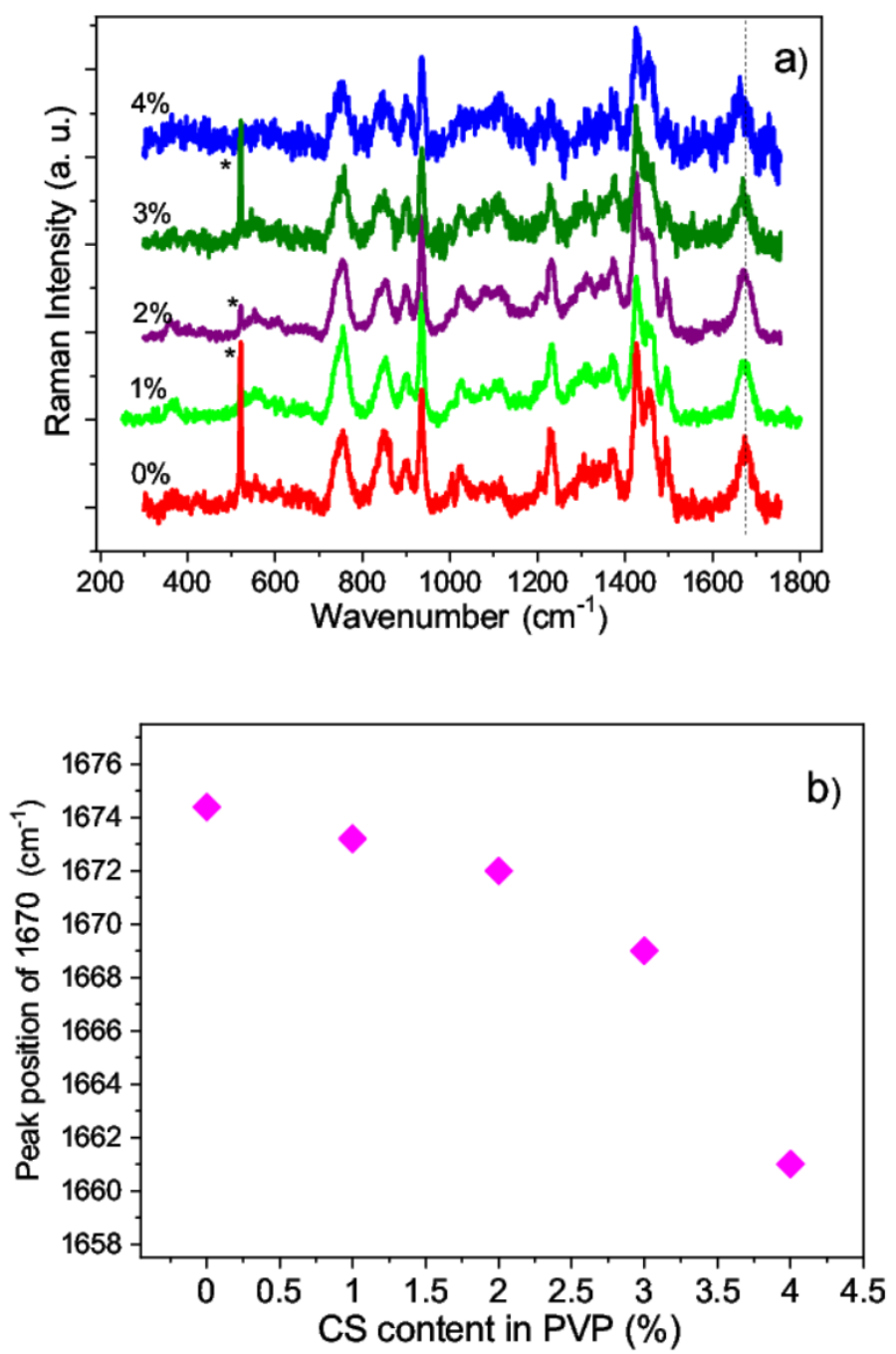

Figure 3. (a) Raman spectra of $\mathrm{x} \% \mathrm{CS} / 6 \% \mathrm{PVP}$ composites with $\times$ values (in percentage) shown beside each of the curves. (b) The dependence of $\mathrm{C}=\mathrm{O}$ band position, obtained after band fitting, vs. CS content. Peak at $520 \mathrm{~cm}^{-1}$ in (a) marked by asterisk is attributed to Si wafer.

However, more detailed analysis revealed that the position of the $\mathrm{C}=\mathrm{O}$ band is downshifted gradually with the increase in CS content and approaching the shift of $13 \mathrm{~cm}^{-1}$ for sample E (40\% CS and 60\% PVP) (see Figure 3b). This shift is due to the hydrogen bonding (H-bonding) between PVP and CS molecules. Similar shifts in Raman spectrum of different polymer blends and complexes were demonstrated in the literature [29-32]. In particular, the significant downshift of carbonyl band was attributed by Hao et al. [31] to H-bonding in complex Gantrez/PVP. The authors provided a detailed explanation why these polymers can form the H-bonding in complex while it does not exist in their pure states. In addition to that, Suknuntha et al. [33] performed a molecular modelling simulation to identify the interacting molecular groups in CS/PVP blends and concluded that the most favourable site for $\mathrm{H}$-bonding formation is with the oxygen atom of $\mathrm{C}=\mathrm{O}$ group of PVP. The $\mathrm{H}$-bonding with $\mathrm{C}=\mathrm{O}$ groups in PVP can be formed by the $-\mathrm{OH}$ and $-\mathrm{NH}_{2}$ groups from chitosan. In addition to H-bonding, CS and PVP may also interact with each other through electrostatic interactions between the negatively charged PVP oxygen atom $\left(\mathrm{N}^{+}=\mathrm{C}-\mathrm{O}-\right)$ and the ionizable amino group of CS $[13,34]$. Further support for the effect of CS presence on CS/PVP fibre composite was obtained from considering the range of spectra of $2730-3100 \mathrm{~cm}^{-1}$ representing the $\mathrm{CH}$ and $\mathrm{CH}_{2}$ stretching vibrations bands [26,28,35], see Figure $4 a, b$. This spectral range fitting with three vibrational bands is shown in Figure 4 a for sample A $(0 \%$ CS), while it is shown in Figure $4 \mathrm{~b}$ for sample E (4\% CS in CS/PVP fibre composite). This 
spectral range has been investigated in various works [32,35-43] for extracting different characteristics of complex blends and macromolecules, including the order/disorder of acyl chain, the degree of acetylation (DA) and degree of deacetylation (DD).
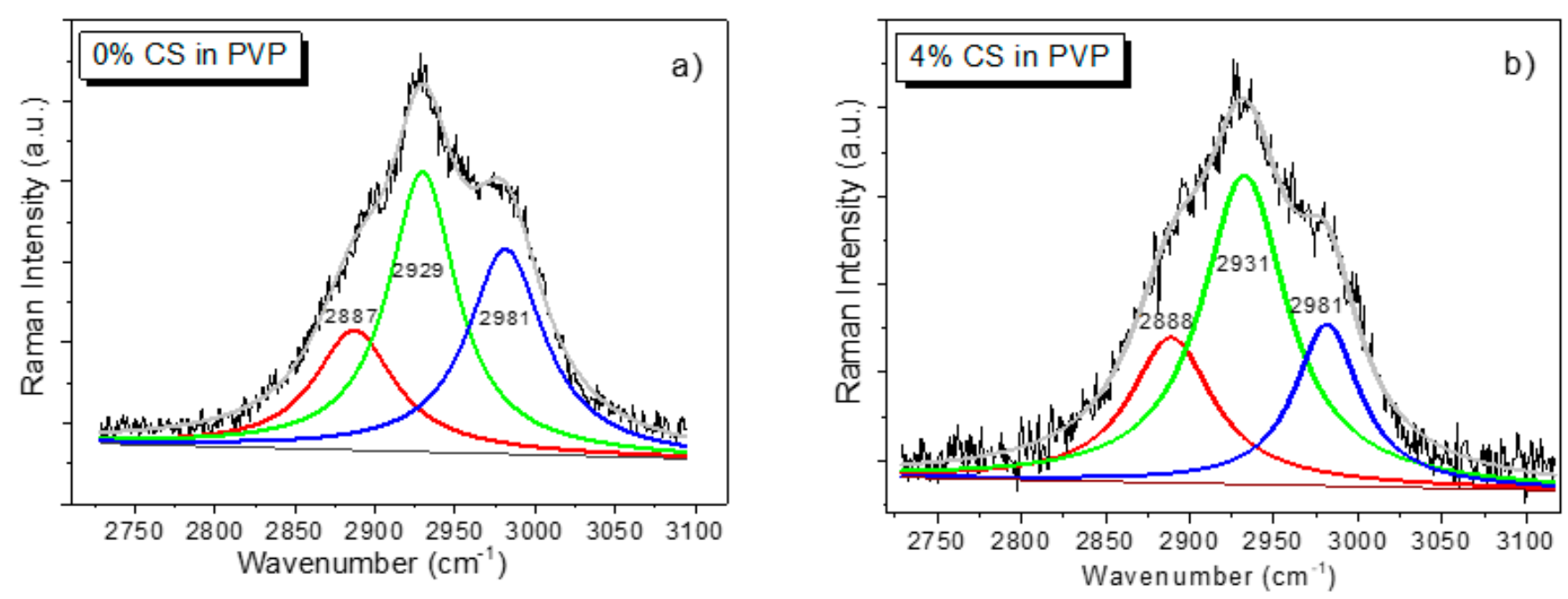

Figure 4. Raman spectra and their fitting in the region of $2720-3130 \mathrm{~cm}^{-1}$ for fibre composites with (a) $0 \%$ CS and (b) $4 \%$ CS.

In our case, we suggest using the ratio of high-frequency bands to demonstrate the contribution of the presence of CS to the vibrational band at $\sim 2930 \mathrm{~cm}^{-1}$ with respect to the band at $2981 \mathrm{~cm}^{-1}$. It was noted that CS/PVP composites show a complex region of $\mathrm{CH}$ and $\mathrm{CH}_{2}$ stretching vibrations with contribution from both type of molecules [36]. Therefore, the ratio of intensities $\mathrm{I}_{2930} / \mathrm{I}_{2981}$ was chosen to characterise the influence of the addition of CS on Raman spectra of CS/PVP composite. This is in accordance with the literature; the $\mathrm{CH}$ stretching bands of stronger intensity appears in CS at 2885 and at $\sim 2930 \mathrm{~cm}^{-1}[35,37,38]$, while in PVP fibres, the most intense bands, depending on molecular weight and state of PVP, are located in the range 2822-2830, 2875-2890, and $2940-2980 \mathrm{~cm}^{-1}[24,29]$. Pure PVP of high molecular weight (K30) shows the most intense $\mathrm{CH}$ stretching bands in the Raman spectrum at 2880, 2930 and $2980 \mathrm{~cm}^{-1}$ [25]. We believe that the ratio of peak intensities $\left(\mathrm{I}_{2930} / \mathrm{I}_{2981}\right)$ or integrated intensities $\left(\mathrm{A}_{2930} / \mathrm{A}_{2980}\right)$ can be considered as a measure of the CS content in the CS/PVP fibre composite, based on the fact that the contribution to the intensity of band at $\sim 2830 \mathrm{~cm}^{-1}$ will be provided by both types of molecules, while the band at $2981 \mathrm{~cm}^{-1}$ is mainly due to the contribution of PVP molecules. Figure $5 \mathrm{a}, \mathrm{b}$ show the dependence of intensity ratios $\left(\mathrm{A}_{2930} / \mathrm{A}_{2981}\right)$ and $\left(\mathrm{I}_{2930} / \mathrm{I}_{2981}\right)$ vs. CS content. It can be seen that these ratios increase in linear range with the increase in CS content from above $1 \%$ CS. Figure $5 \mathrm{c}$ shows the dependence of the position of the peaks, obtained during the fitting and support that the fitting of these complex bands was performed reliably. 

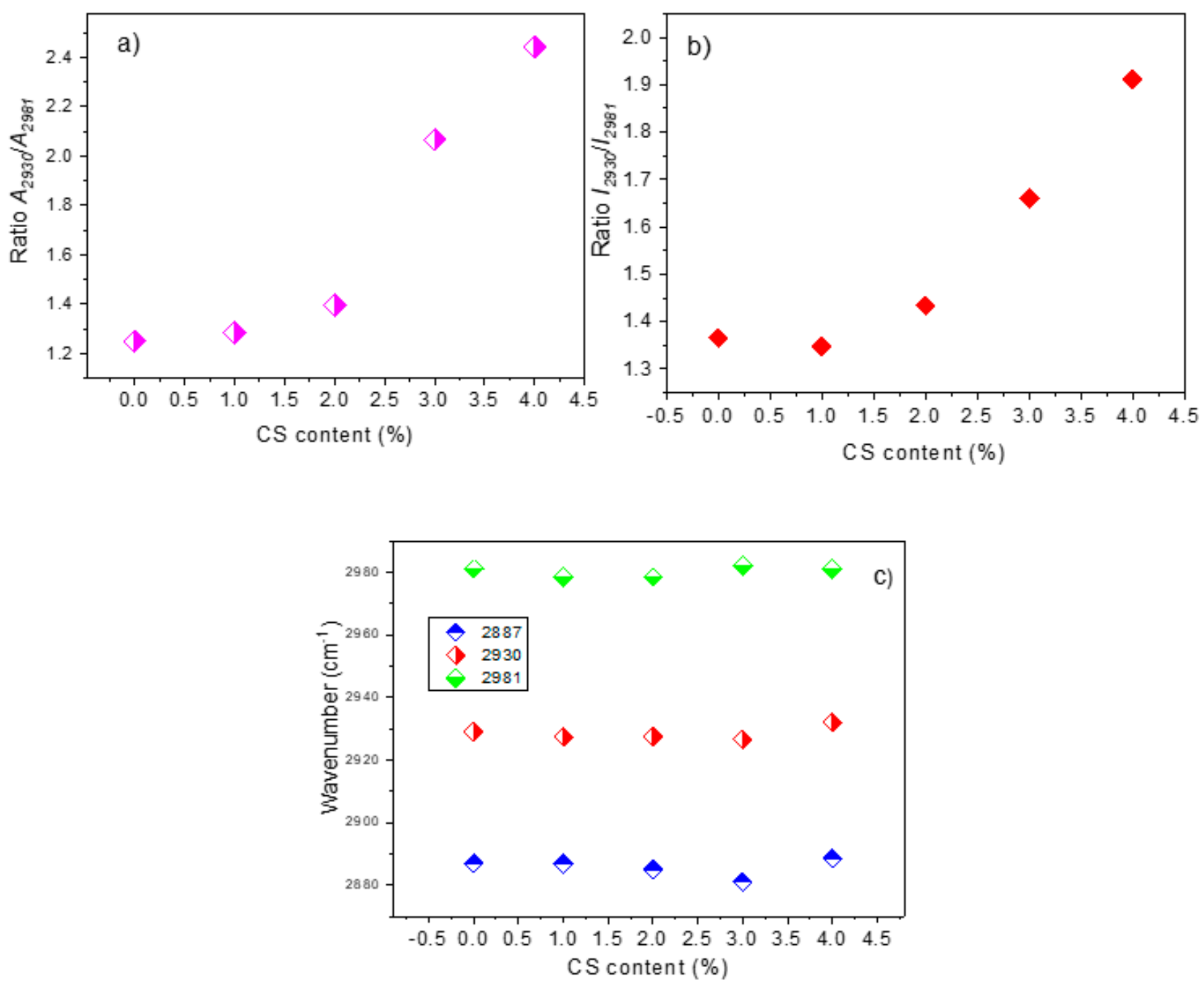

Figure 5. The dependence of ratios of (a) integrated intensities $A_{2930} / A_{2981}$ and (b) peak intensities $I_{2930} / I_{2981}$ of bands at $2930 \mathrm{~cm}^{-1}$ and $2981 \mathrm{~cm}^{-1}$, obtained after fitting the high-frequency band in the range $2720-3130 \mathrm{~cm}^{-1}$ shown in Figure 4 . (c) The dependence of peak positions of three bands at 2887, 2930 and $2981 \mathrm{~cm}^{-1}$ obtained during fitting. No significant changes in these peak positions are seen for all three bands at different CS content.

In addition to the changes observed in Raman spectra of PVP/CS fibre composites at the increase in CS content, relatively small shifts in the peak position of some other bands were also observed. In particular, the band of pyrrolidone group shifted from $1424 \mathrm{~cm}^{-1}$ in sample A (at $0 \% \mathrm{CS}$ ) to $1427 \mathrm{~cm}^{-1}$ in sample $\mathrm{E}$ (at $4 \% \mathrm{CS}$ ); the $\mathrm{CH}$ bending band seen at $1371 \mathrm{~cm}^{-1}$ in sample A ( $\left.0 \% \mathrm{CS} / 6 \% \mathrm{PVP}\right)$ shifted to $1374 \mathrm{~cm}^{-1}$ in sample E $(4 \% \mathrm{CS} / 6 \% \mathrm{PVP})$.

Therefore, we can conclude that despite initial analysis showing that a small percentage presence of CS in PVP does not affect the Raman spectra significantly, a more detailed analysis of band position and deconvolution of some complex bands can result in reliable information on CS content in CS/PVP composite fibres. One of the differences in larger contribution from CS molecules to the higher-frequency range of Raman spectra (2730-3100 $\mathrm{cm}^{-1}$ ) could be because the intensities of Raman bands for CS in this region are much stronger in comparison with the low-frequency region. This follows from our measurements and correlates with previous studies $[37,38]$. 


\subsubsection{FTIR Spectroscopy}

Due to the presence of environmental moisture when using our ATR-FTIR setup, the measured IR spectra in the regions from $1300 \mathrm{~cm}^{-1}$ to $2000 \mathrm{~cm}^{-1}$ and around $3000-3900 \mathrm{~cm}^{-1}$ are modulated by the narrow rotational bands of water (see examples shown in Figure 6a). Therefore, we mainly focus our discussion on the region $900-1300 \mathrm{~cm}^{-1}$, where some vibrational bands typical for CS may present [12,39-43]. Before moving to this discussion, it is worth noting that the carbonyl band $(\mathrm{C}=\mathrm{O})$, which can be seen clearly in Figure $6 \mathrm{a}$, is gradually downshifted from its original position at $1661 \mathrm{~cm}^{-1}$ in sample A to $1557 \mathrm{~cm}^{-1}$ for sample E. This confirms the influence of intermolecular interactions (namely $\mathrm{H}$-bonding) on the position of $\mathrm{C}=\mathrm{O}$ band and was previously described in a number of papers $[13,29,43,44]$ devoted to FTIR investigation of polymer fibre composites and blends. As was reported in earlier studies of different research groups $[29,45,46]$, the H-bonding in complex polymers is considered to be strong if the carbonyl band position is located below $1661 \mathrm{~cm}^{-1}$. This is also in agreement with the Raman data described above; however, the downshift of $\mathrm{C}=\mathrm{O}$ band in FTIR spectra of the investigated CS/PVP fibre composites is not as dramatic. One of the reasons for this difference may lie in the fact that during micro-Raman spectroscopy investigations, a laser beam (of 1-2 $\mu \mathrm{m}$ in diameter) was focused on one fibre, and, therefore, only a small area of the sample surface was tested, whereas in case of ATR-FTIR measurements, the signal from a much larger surface and depth of sample was collected and averaged.

In general, the bands at $1000-1200 \mathrm{~cm}^{-1}$ are attributed to the saccharide structure of chitosan and seen in particular at 1154, 1073 and $1032 \mathrm{~cm}^{-1}$ [40] in pure CS. FTIR spectra, truncated in the region of $900-1370 \mathrm{~cm}^{-1}$, for all investigated CS/PVP composites, are shown in Figure $6 \mathrm{~b}$. From this figure it is clear that even at 1\% CS, some additional bands to that, demonstrated in the IR spectrum of $0 \%$ CS, appear in the region $1000-1100 \mathrm{~cm}^{-1}$, as well as some noticeable changes in peak positions and relative intensity of vibrational bands in the region 1100-1200 $\mathrm{cm}^{-1}$. In particular, C-C stretching is located at $1131 \mathrm{~cm}^{-1}$, while skeletal vibrations involving the $\mathrm{C}-\mathrm{O}$ stretching typical for $\mathrm{CS}$ saccharide structure are observed at 1030 and $1076 \mathrm{~cm}^{-1}$ [39-42]. The behaviour of these bands, as well as the band at $1175 \mathrm{~cm}^{-1}$ was analysed versus CS content after fitting the spectra in the range $900-1300 \mathrm{~cm}^{-1}$ using Renishaw Wire 3.2 software (see examples in Figure $7 \mathrm{a}, \mathrm{b}$ ). The results extracted from the spectral fitting are summarized in Figure 8a-d. In particular, the dependence of the absorbance peak intensity vs. CS content is shown for C-O band at $1030 \mathrm{~cm}^{-1}$ in Figure 8a, while the integrated intensity of the band at $1076 \mathrm{~cm}^{-1}$ vs. CS content is shown in Figure 8b. Both graphs demonstrate a linear increase in band intensity when the CS content is increased. In addition to that, the band at around $\sim 1130 \mathrm{~cm}^{-1}$ shows the downshift from its original position at $1137 \mathrm{~cm}^{-1}$ for $0 \%$ of CS to $1130 \mathrm{~cm}^{-1}$ for sample $\mathrm{E}(4 \% \mathrm{CS} / 6 \% \mathrm{PVP})$. Only a slight increase in the intensity of this band is seen from Figure 8c. 

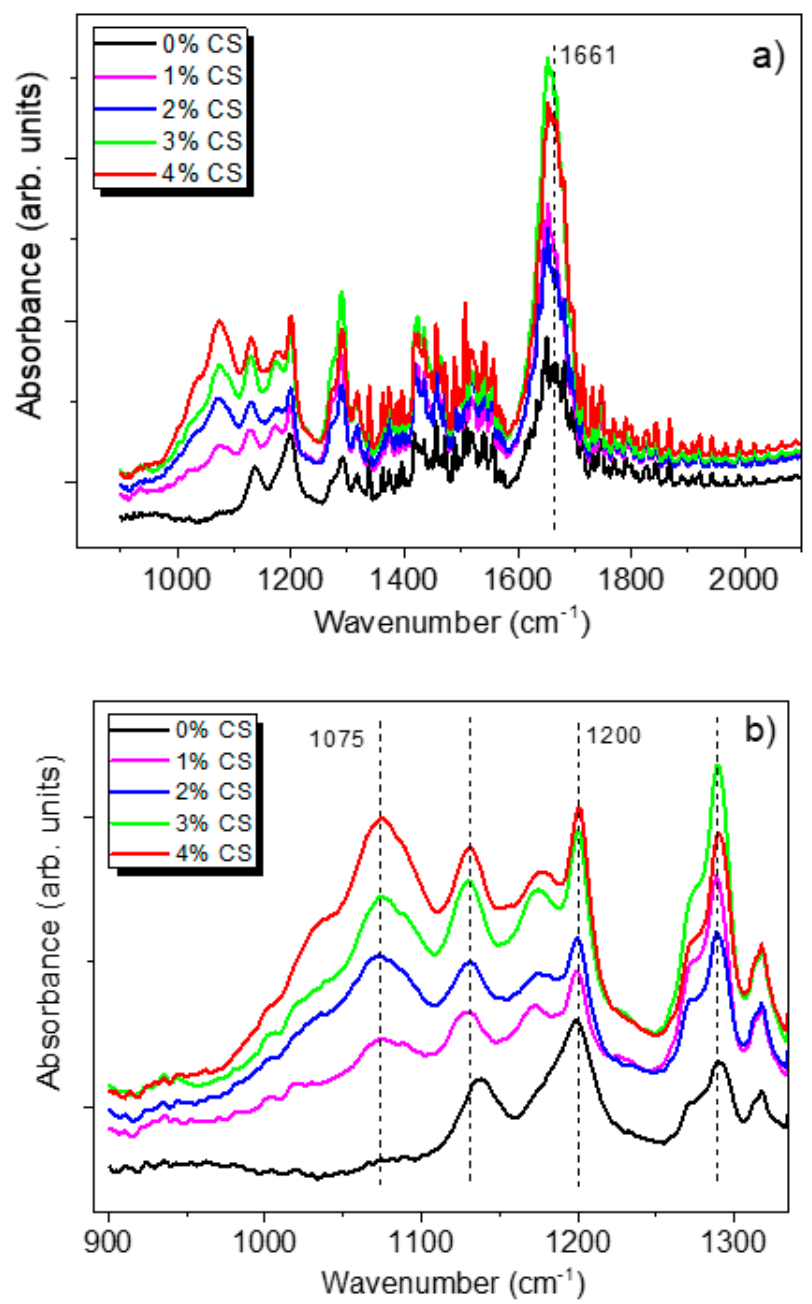

Figure 6. FTIR spectra of $\mathrm{x} \% \mathrm{CS}+6 \% \mathrm{PVP}$ fibre composites with $\mathrm{x}$ varied from $0 \%$ to $4 \%$ in the regions (a) $900-2100 \mathrm{~cm}^{-1}$ (showing modulation of spectra by rotational bands of water) and (b) in the region 900-1350 $\mathrm{cm}^{-1}$ where bands corresponding to CS increases in intensity at the increase in CS content. Vertical dashed lines show some peak position.

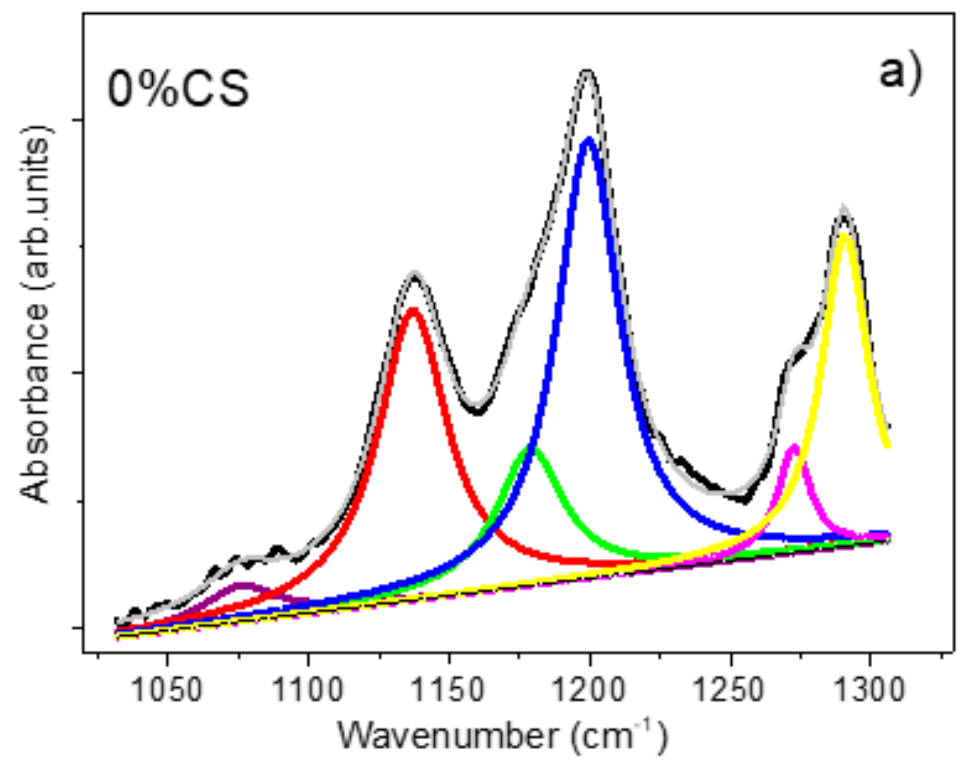

Figure 7. Cont. 


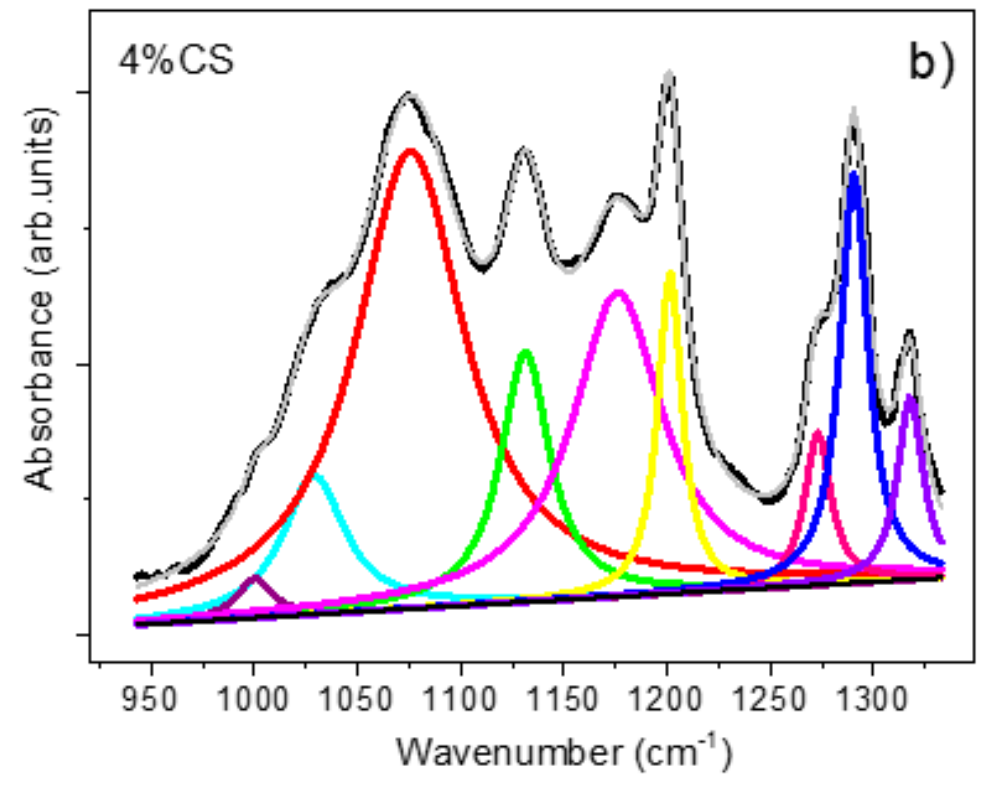

Figure 7. Fitting of FTIR spectra in the region $900-1350 \mathrm{~cm}^{-1}$ for (a) sample A $(0 \% \mathrm{CS} / \% \mathrm{PVP})$ and (b) sample E (4\%CS/6\%PVP): the black line corresponds to the experimental spectrum, the grey line corresponds to the fitting envelope and the colour lines correspond to different contribution bands.
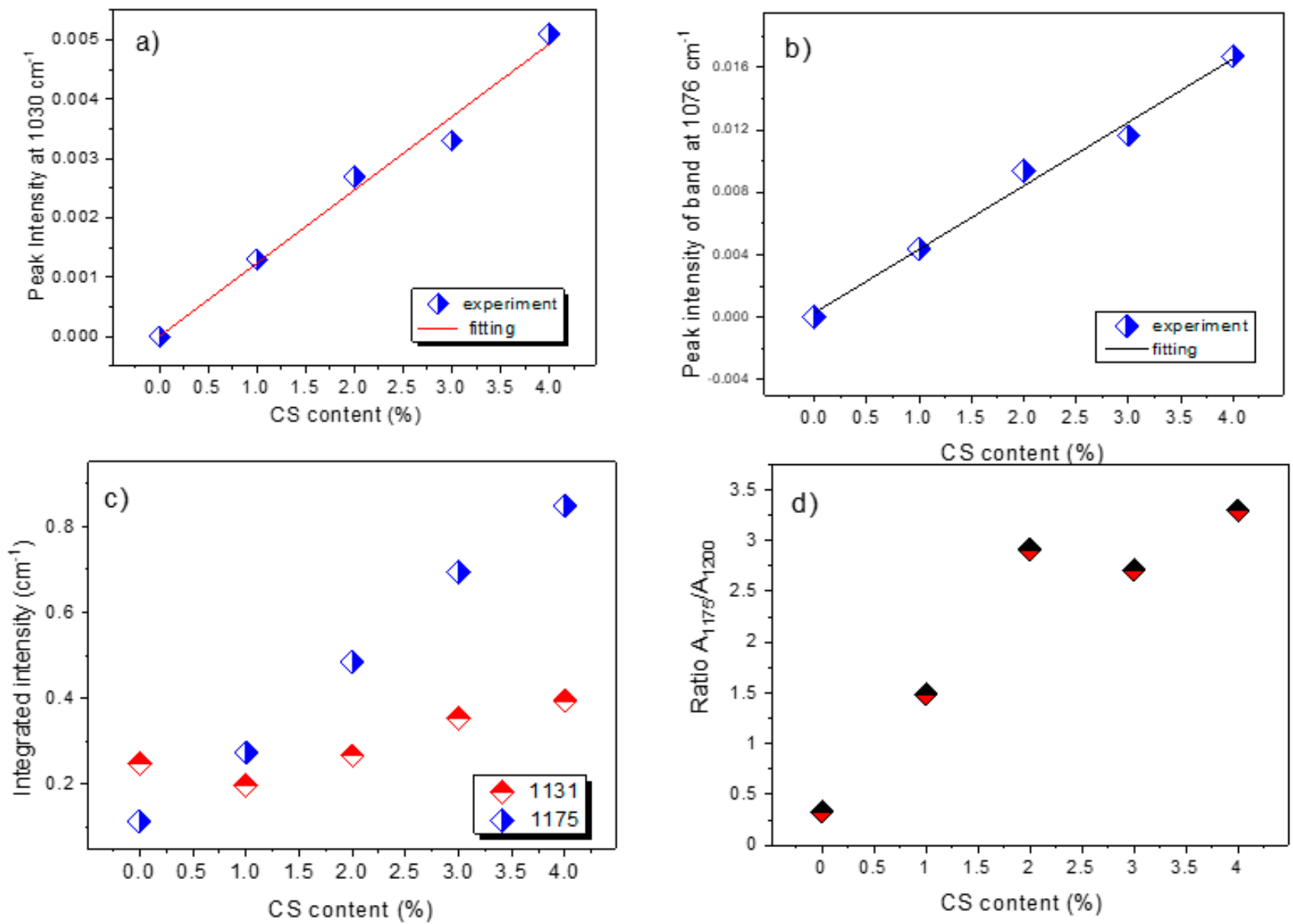

Figure 8. The dependence of the peak intensity vs CS content for C-O stretching vibrational bands at (a) 1030 and (b) $1076 \mathrm{~cm}^{-1}$ obtained after FTIR spectra fitting in the region $900-1250 \mathrm{~cm}^{-1}$. The dependence of (c) the integrated intensity of bands at 1131 and $1175 \mathrm{~cm}^{-1}$ and (d) the integrated intensity ratio of (A1175/A1200) vs. CS content obtained after FTIR spectra fitting in the region $900-1350 \mathrm{~cm}^{-1}$ as shown in Figure 7. 
In addition, the band at $1178 \mathrm{~cm}^{-1}$ demonstrates a slight downshift to $1175 \mathrm{~cm}^{-1}$ and a significant increase in integrated intensity vs. CS content (Figure 8c). In accordance with FTIR bands assignment, the vibrational bands in this region may belong to $\mathrm{CH}_{2}$ twist in PVP molecules [24] and to the antisymmetric stretching of C-O-C bridge [40,43], to C-C stretching vibration [41] and to some combinational bands [35] in chitosan. At the same time, it can be also seen from Figure $7 \mathrm{a}, \mathrm{b}$ that the vibrational band at $\sim 1200 \mathrm{~cm}^{-1}$, which exists in the original spectrum for sample A $(0 \% \mathrm{CS} / 6 \% \mathrm{PVP}$ composite), does not demonstrate a significant change in the peak position or the peak intensity at higher CS content. This band can be used as a reference for estimating the ratio of peak intensities in order to prove the increase in intensity for band at $1175 \mathrm{~cm}^{-1}$. The graph of dependence of the integrated intensities ratio of band $\mathrm{A}_{1175}$ to typical PVP band at $1200 \mathrm{~cm}^{-1}$ (i.e., $\left.A_{1175} / A_{1200}\right)$ vs. CS content was plotted in Figure $8 d$. As can be seen from Figure $8 d$, this ratio also demonstrates a reasonable linear dependence with increasing CS content and confirms that the band fitting procedure was reliable.

Therefore, based on FTIR spectral analysis, we can not only get the confirmation on the presence of CS in CS/PVP fibre composites but also a quantitative estimation of the CS content using reference linear dependence of the intensity of C-O bands at 1030 and $1076 \mathrm{~cm}^{-1}$. FTIR investigation also provides a solid support to the conclusion drawn in the previous Section based on Raman data.

It should be noted here that in the FTIR spectra of the PVP and CS electrospun fibres, the intensities of high-frequency bands are much lower than the intensities of lowfrequency vibrational bands which is opposite to the case in the Raman spectra discussed in Section 3.2.3 (see also [24,30,35,37]).

\subsection{Drug Incorporation}

5-fluorouracil is an anti-cancer drug commonly used for the treatment of cancer relating to the human colon, stomach, oesophagus, etc. It was chosen as a model therapeutic to load into the CS:PVP system due to its hydrophilicity and the hydrophilicity of the polymers. This should help the miscibility of the blend and thus loading capacity in the fibres. 5-Fu at different concentrations was added to the 4:6 CS:PVP blend and electrospun using instrumentation parameters of; $15 \mathrm{kV}, 15 \mathrm{~cm}$ tip-collector gap, $0.2 \mathrm{~mL} / \mathrm{h}^{-1}$ and an 18-gauge needle. The 4:6 CS:PVP blend was chosen here as it contained the highest concentration of CS. This is critical for improving the biocompatibility and drug loading properties of the composite.

\section{Cell Viability Study}

A549 human lung epithelial adenocarcinoma cells were chosen as a model cell line to analyse the cytotoxicity of electrospun constructs containing CS/PVP, along with 5-Fu loaded CS/PVP constructs $(1,5$ and $10 \mathrm{mg} / \mathrm{mL})$. A WST- 8 assay was chosen for cell viability analysis. Following exposure of the cells to electrospun constructs for $24 \mathrm{~h}$, there was no statistical difference between cells alone and the CS/PVP construct, as seen in Figure 9, meaning that the CS/PVP construct did not have a toxic effect on the cells. Research has shown that CS containing nanofibres have "remedying effects" when exposed to normal cells which have been previously exposed to 5-Fu [47]. Additionally, studies have shown that CS containing electrospun nanofibres were non-toxic to cells [48] in agreement to the results we have obtained. Research has also detailed the non-toxic effect of CS within a polymer matrix (PVA and PLA in this case) towards MCF-7 breast cancer cell lines [49]. 


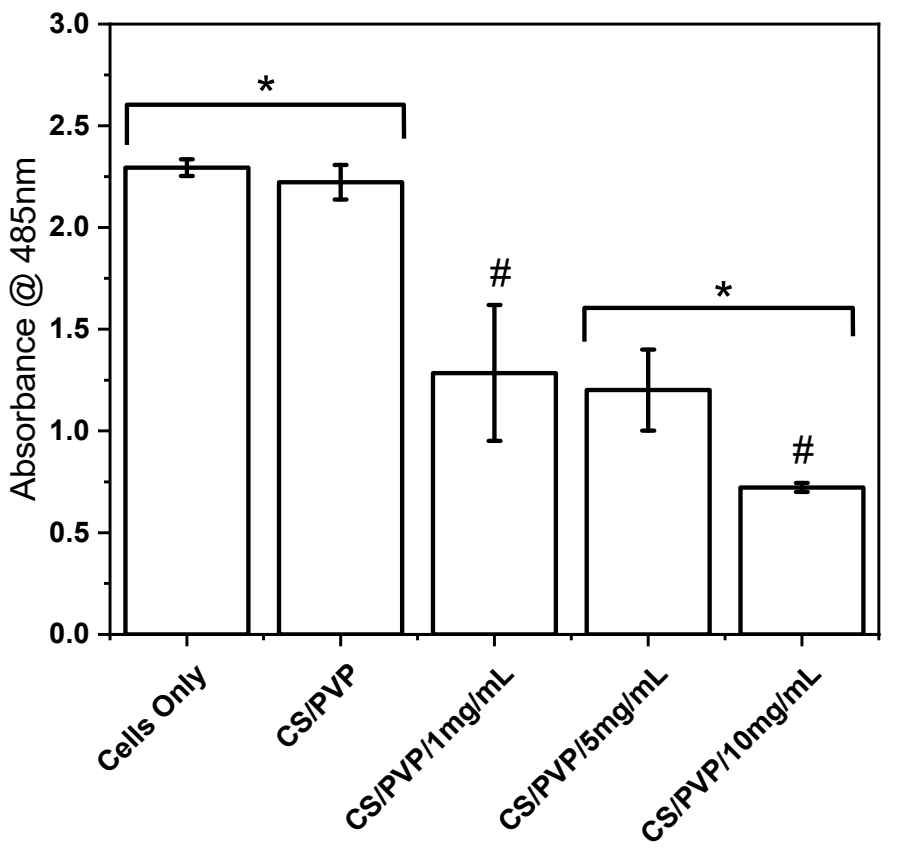

Figure 9. Cell viability measured using a WST- 8 assay after $24 \mathrm{~h}$ exposure to constructs $\left(37^{\circ} \mathrm{C}, 5 \%\right.$ $\mathrm{CO}_{2}$ ). Absorbance was measured at $485 \mathrm{~nm}$; high absorbance indicates high cell viability. Groups containing 1, 5 and $10 \mathrm{mg} / \mathrm{mL}$ all contained 5-Fu. Here, ${ }^{*}$ denotes statistical significance between control groups and experimental groups containing 5-Fu. \# denotes statistical significance between concentrations of 5-Fu in the CS/PVP groups. Two sample $t$-test, $p<0.05, n=3$.

Statistically, there was a difference between the control groups (cells alone and CS/PVP construct) and both the 5 and $10 \mathrm{mg} / \mathrm{mL} 5$-Fu containing group, which means at both of these concentrations, the drug was efficient at killing cells (Figure 9). The construct containing $1 \mathrm{mg} / \mathrm{mL}$ drug also showed increased cell death compared to controls, but this was not statistically significant-1 $\mathrm{mg} / \mathrm{mL} 5-\mathrm{Fu}$ was not a high enough concentration to kill cells efficiently. Due to the statistical difference in cell death between drug loaded and non-drug loaded groups, and the increase in cell death as the drug concentration is increased (strong negative correlation (no significant) by Pearson's correlation test; $\mathrm{r}=-0.86, p=0.06$ ), we can ascertain that the cell death is due to drug release alone. There was also a statistical difference between the 1 and $10 \mathrm{mg} / \mathrm{mL} 5$-Fu containing groups$1 \mathrm{mg} / \mathrm{mL} 5-\mathrm{Fu}$ was not a high enough concentration to kill cells efficiently. Generally, over $24 \mathrm{~h}, 5-\mathrm{Fu}$ is released by an initial burst followed by a slower release phase [50]. The release mechanism of 5-Fu from nanofibres is generally through a Fickian diffusion mechanism $[18,19]$. Release is related to the diffusion or permeation of the drug through nanofibre mat matrices [18,49]. It has been shown that the inclusion of CS and PVP in a 5-Fu delivery system can increase drug exposure time in comparison to 5-Fu only [51] as well as greatly inhibiting tumour growth [51-54].

Further analysis of the $24 \mathrm{~h}$ WST- 8 assay shows that the cell viability decreased from $96.93 \%$ to; $56 \%(1 \mathrm{mg} / \mathrm{mL}), 52.35 \%(5 \mathrm{mg} / \mathrm{mL})$ and $31.48 \%(10 \mathrm{mg} / \mathrm{mL})$, as seen in Figure 10. There is a strong negative correlation between drug concentration and cell viability, as identified by Pearson's correlation test [55], but it is not statistically significant owing to the small number of $\mathrm{x}$-variables $(\mathrm{r}=-0.84, p=0.07)$. Overall, $10 \mathrm{mg} / \mathrm{mL}$ drug concentration was most efficient at killing cells. It has been reported that CS containing 5-Fu composites decrease cell viability of cancer cells up to $\geq 50 \%$ over $24 \mathrm{~h}$ [19]. Other analysis has shown that it may take up to $48 \mathrm{~h}$ to efficiently kill $\geq 50 \%$ of liver cancer cells (HepG2) in electrospun CS/5-Fu delivery vehicles [56]. A 30\% viability due to 5-Fu release at $24 \mathrm{~h}$, as seen in our study, concurs with other published studies; 5 -Fu release from chitosan grafted poly(N-vinylcaprolactam) to PC3, KB and MCF7 cancer cell lines showed similar toxicity levels at $24 \mathrm{~h}$ for a $1 \mathrm{mg} / \mathrm{mL}$ loaded chitosan sample [54]. The 
viability of MCF7 breast cancer cells exposed to electrospun chitosan composites containing 5 -Fu showed $60 \%$ viability after $24 \mathrm{~h}$, but viability decreased further over time and was dependent on the composite materials and processing parameters [50].

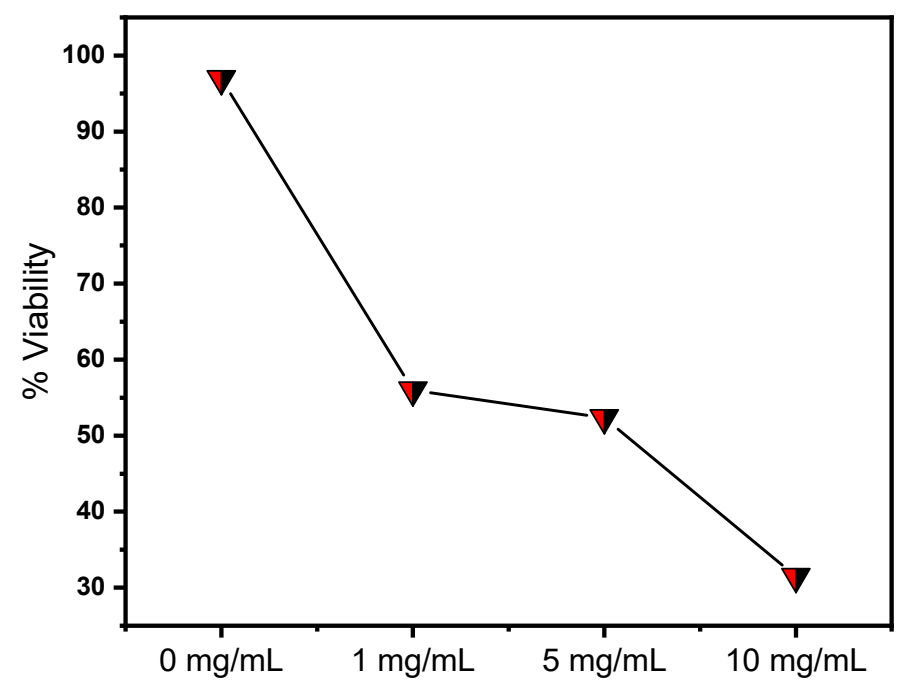

Figure 10. \% Cell viability measured using a WST- 8 assay after $24 \mathrm{~h}$ exposure to constructs $\left(37^{\circ} \mathrm{C}, 5 \%\right.$ $\mathrm{CO}_{2}$ ). Viability was calculated using the following formula: [A549 (sample)/A549 (control)] $\times 100$.

The inclusion of a higher CS content in a polymeric blend has been shown to improve drug loading and release properties. This is because of interactions between CS and 5$\mathrm{Fu}$ [18]. Following the above fibre production protocol that we developed, we achieved fibres containing a high ratio of CS to PVP (4:6) which shows good potential for use in a drug delivery system. Moving forward, a concentration between 5 and $10 \mathrm{mg} / \mathrm{mL} 5-\mathrm{Fu}$ will be chosen to exploit the cytotoxic properties of the material for cancer research. The biggest limitation to the work is in converting our in vitro results to the in vivo scenario. To move forward, our electrospun constructs will be made using our chosen 'tuned' parameters to the relevant anatomical size and re-assessed for drug release and cell viability in a scaled-up culture system. An in vivo study investigating 5-Fu release from electrospun PLLA mats used tumour-bearing mice; drug loaded electrospun mats were surgically implanted onto the tumour site and the tumour size assessed daily. The drug loaded mats showed increased tumour suppression and necrosis and increased survival time in treatment groups compared to control groups and results correlated with the preceding in vitro work performed [3]. Therefore, it is encouraging that our in vitro work outlined here will translate to a clinical application as we advance our research.

Note, that the additional information on drug release profile and degradation rate study is provided in the Supplementary Materials Section.

\section{Conclusions}

Overall, sample E, containing 4\% chitosan and 6\% PVP, proved to be the best performing fibres and presented characteristics of unaltered chitosan and PVP. This sample was achieved under the following electrospinning protocol; voltage set at $15 \mathrm{kV}$, tip-collector gap set at $15 \mathrm{~cm}$ with a flow rate of $0.1 \mathrm{~mL} \mathrm{~h}^{-1}$. The content of chitosan incorporated in the fibres is very significant. This concentration of chitosan is higher than anything that has been reported in the previous literature when forming a blend with another polymer $[13,57]$. Chitosan and PVP presented un-altered features post-electrospinning.

The SEM results show that the morphological structure of sample E fully homogenous with no heterogeneities (i.e., beads) observed within the investigated structure. XPS showed that the surface composition of the materials contained PVP. However, intermolecular interactions (via H-bonding) between PVP and CS molecules analysed in Raman and FTIR data indicate the presence of CS within the samples. In terms of cell viability studies, 
constructs containing $10 \mathrm{mg} / \mathrm{mL}$ of the drug were the most efficient at killing cells over $24 \mathrm{~h}$. The constructs containing $1 \mathrm{mg} / \mathrm{mL}$ of the drug were not efficient at killing cells. The study concludes that chitosan-based electrospun constructs have potential in the use of drug delivery systems. Further research would be performed to optimise drug delivery of chitosan/PVP/5-Fu constructs to human lung cancer cells.

Supplementary Materials: The following are available online at https://www.mdpi.com/article/10 $.3390 /$ chemosensors $9040070 / \mathrm{s} 1$, Figure S1. 5-Fu released $(\mu \mathrm{g} / \mathrm{mL})$ from samples $1 \mathrm{mg} / \mathrm{mL}, 5 \mathrm{mg} / \mathrm{mL}$ and $10 \mathrm{mg} / \mathrm{mL}$ at 3, 24- and 48-h time points; Figure S2. Cumulative release of 5-Fu $(\mu \mathrm{g} / \mathrm{mL})$ from samples $1 \mathrm{mg} / \mathrm{mL}, 5 \mathrm{mg} / \mathrm{mL}$ and $10 \mathrm{mg} / \mathrm{mL}$ 5-Fu after 3, 24 and $48 \mathrm{~h}$; Figure S3. Cumulative drug release $(\mu \mathrm{g} / \mathrm{mL})$ vs $\%$ cell viability at each concentration $(0,1,5,10 \mathrm{mg} / \mathrm{mL})$; Table $\mathrm{S} 1$. Concentrations of PVP and CS in specific solvent systems along with the electrospinning results obtained; Table S2. instrumentation parameters that have been tested to produce robust electrospun fibres.

Author Contributions: Conceptualization, S.H.; Data curation, S.H.; Formal analysis, M.M.; Investigation, S.H., S.J.H. and A.B.; Methodology, J.J.G.; Project administration, S.C.P.; Writing-review \& editing, T.S.P. and S.H. Each author contributed to the conceptualization, investigation, data curation, writing and reviewing of this work. All authors have read and agreed to the published version of the manuscript.

Funding: This research received no external funding.

Institutional Review Board Statement: Not applicable.

Informed Consent Statement: Not applicable.

Data Availability Statement: Not applicable.

Acknowledgments: This work received the financial support from the President's Bursary, Institute of Technology, Sligo, Ireland. We would also like to thank CRANN Institute (Advanced Microscopy Laboratory), Trinity College Dublin, Ireland, for the use of their Scanning Electron Microscope.

Conflicts of Interest: The authors declare no conflict of interest.

\section{References}

1. Balan, P.; Indrakumar, J.; Murali, P.; Korrapati, P.S. Bi-faceted delivery of phytochemicals through chitosan nanoparticles impregnated nanofibers for cancer therapeutics. Int. J. Biol. Macromol. 2020, 142, 201-211. [CrossRef] [PubMed]

2. Khodadadi, M.; Alijani, S.; Montazeri, M.; Esmaeilizadeh, N.; Sadeghi-Soureh, S.; Pilehvar-Soltanahmadi, Y. Recent advances in electrospun nanofiber-mediated drug delivery strategies for localized cancer chemotherapy. J. Biomed. Mater. Res. Part A 2020, 108, 1444-1458. [CrossRef]

3. Zhang, J.; Wang, X.; Liu, T.; Liu, S.; Jing, X. Antitumor activity of electrospun polylactide nanofibers loaded with 5-fluorouracil and oxaliplatin against colorectal cancer AU—Zhang, Jiayu. Drug Deliv. 2016, 23, 794-800. [CrossRef]

4. Hu, X.L.; Liu, S.; Zhou, G.Y.; Huang, Y.B.; Xie, Z.G.; Jing, X.B. Electrospinning of polymeric nanofibers for drug delivery applications. J. Control. Release 2014, 185, 12-21. [CrossRef]

5. Chou, S.F.; Carson, D.; Woodrow, K.A. Current strategies for sustaining drug release from electrospun nanofibers. J. Control. Release 2015, 220, 584-591. [CrossRef] [PubMed]

6. Kalantari, K.; Afifi, A.M.; Jahangirian, H.; Webster, T.J. Biomedical applications of chitosan electrospun nanofibers as a green polymer-Review. Carbohydr. Polym. 2019, 207, 588-600. [CrossRef]

7. Roozbahani, F.; Sultana, N.; Ismail, A.F.; Nouparvar, H. Effects of Chitosan Alkali Pretreatment on the Preparation of Electrospun PCL/Chitosan Blend Nanofibrous Scaffolds for Tissue Engineering Application. J. Nanomater. 2013. [CrossRef]

8. Augustine, R.; Rehman, S.R.U.; Ahmed, R.; Zahid, A.A.; Sharifi, M.; Falahati, M.; Hasan, A. Electrospun chitosan membranes containing bioactive and therapeutic agents for enhanced wound healing. Int. J. Biol. Macromol. 2020, 156, 153-170. [CrossRef]

9. Singare, D.S.; Marella, S.; Gowthamrajan, K.; Kulkarni, G.T.; Vooturi, R.; Rao, P.S. Optimization of formulation and process variable of nanosuspension: An industrial perspective. Int. J. Pharm. 2010, 402, 213-220. [CrossRef] [PubMed]

10. Risbud, M.V.; Hardikar, A.A.; Bhat, S.V.; Bhonde, R.R. pH-sensitive freeze-dried chitosan-polyvinyl pyrrolidone hydrogels as controlled release system for antibiotic delivery. J. Control. Release 2000, 68, 23-30. [CrossRef]

11. Archana, D.; Singh, B.K.; Dutta, J.; Dutta, P. In vivo evaluation of chitosan-PVP-titanium dioxide nanocomposite as wound dressing material. Carbohydr. Polym. 2013, 95, 530-539. [CrossRef]

12. Marsano, E.; Vicini, S.; Skopinska, J.; Wisniewski, M.; Sionkowska, A. Chitosan and poly (vinyl pyrrolidone): Compatibility and miscibility of blends. In Macromolecular Symposia; Wiley: Hoboken, NJ, USA, 2004; pp. 251-260.

13. Yu, D.-G.; Williams, G.R.; Yang, J.-H.; Wang, X.; Qian, W.; Li, Y. Chitosan Nanoparticles Self-Assembled from Electrospun Composite Nanofibers. J. Text. Sci. Eng. 2012, 2. [CrossRef] 
14. Homayoni, H.; Ravandi, S.A.H.; Valizadeh, M. Electrospinning of chitosan nanofibers: Processing optimization. Carbohydr. Polym. 2009, 77, 656-661. [CrossRef]

15. Geng, X.; Kwon, O.-H.; Jang, J. Electrospinning of chitosan dissolved in concentrated acetic acid solution. Biomaterials 2005, 26, 5427-5432. [CrossRef] [PubMed]

16. Ohkawa, K.; Cha, D.; Kim, H.; Nishida, A.; Yamamoto, H. Electrospinning of chitosan. Macromol. Rapid Commun. 2004, 25, 1600-1605. [CrossRef]

17. Dhanavel, S.; Revathy, T.; Sivaranjani, T.; Sivakumar, K.; Palani, P.; Narayanan, V.; Stephen, A. 5-Fluorouracil and curcumin co-encapsulated chitosan/reduced graphene oxide nanocomposites against human colon cancer cell lines. Polym. Bull. 2020, 77, 213-233. [CrossRef]

18. Hadjianfar, M.; Semnani, D.; Varshosaz, J. Polycaprolactone/chitosan blend nanofibers loaded by 5-fluorouracil: An approach to anticancer drug delivery system. Polym. Adv. Technol. 2018, 29, 2972-2981. [CrossRef]

19. Patel, G.; Yadav, B.K. Formulation, Characterization and In vitro Cytotoxicity of 5-Fluorouracil Loaded Polymeric Electrospun Nanofibers for the Treatment of Skin Cancer. Recent Pat. Nanotechnol. 2019, 13, 114-128. [CrossRef]

20. Yuya, N.; Kai, W.; Kim, B.-S.; Kim, I. Morphology controlled electrospun poly (Vinyl Pyrrolidone) fibers: Effects of organic solvent and relative humidity. J. Mater. Sci. Eng. Adv. Technol. 2010, 2, 97-112.

21. Amariei, N.; Manea, L.; Bertea, A.; Bertea, A.; Popa, A. The influence of polymer solution on the properties of electrospun 3D nanostructures. In IOP Conference Series: Materials Science and Engineering; IOP: Bristol, UK, 2017; p. 012092.

22. Yener, F.; Jirsak, O.; Gemci, R. Effect of polymer concentration on electrospinning System. In Proceedings of the Conference: Fiber Society Conference, Bursa, Turkey, 5-7 May 2010.

23. Maachou, H.; Genet, M.J.; Aliouche, D.; Dupont-Gillain, C.C.; Rouxhet, P.G. XPS analysis of chitosan-hydroxyapatite biomaterials: From elements to compounds. Surf. Interface Anal. 2013, 45, 1088-1097. [CrossRef]

24. Borodko, Y.; Habas, S.E.; Koebel, M.; Yang, P.; Frei, H.; Somorjai, G.A. Probing the Interaction of Poly (vinylpyrrolidone) with Platinum Nanocrystals by UV-Raman and FTIR. J. Phys. Chem. B 2006, 110, 23052-23059. [CrossRef]

25. Fini, A.; Cavallari, C.; Ospitali, F. Raman and thermal analysis of indomethacin/PVP solid dispersion enteric microparticles. Eur. J. Pharm. Biopharm. 2008, 70, 409-420. [CrossRef]

26. Socrates, G. Infrared and Raman Characteristic Group Frequencies, 3rd ed.; John Wiley \& Sons: Hoboken, NJ, USA, 2001.

27. De Faria, D.; Gil, H.; De Queiroz, A. The interaction between polyvinylpyrrolidone and I2 as probed by Raman spectroscopy. J. Mol. Struct. 1999, 478, 93-98. [CrossRef]

28. Pérez, S.; Rebollar, E.; Oujja, M.; Martín, M.; Castillejo, M. Laser-induced periodic surface structuring of biopolymers. Appl. Phys. A 2013, 110, 683-690. [CrossRef]

29. Rahma, A.; Munir, M.M.; Prasetyo, A.; Suendo, V.; Rachmawati, H. Intermolecular interactions and the release pattern of electrospun curcumin-polyvinyl (pyrrolidone) fiber. Biol. Pharm. Bull. 2016, 39, 163-173. [CrossRef] [PubMed]

30. Szaraz, I.; Forsling, W. A spectroscopic study of the solvation of 1-vinyl-2-pyrrolidone and poly (1-vinyl-2-pyrrolidone) in different solvents. Polymer 2000, 41, 4831-4839. [CrossRef]

31. Hao, J.S.; Chan, L.W.; Shen, Z.X.; Heng, P.W. Complexation between PVP and Gantrez polymer and its effect on release and bioadhesive properties of the composite PVP/Gantrez films. Pharm. Dev. Technol. 2005, 9, 379-386. [CrossRef]

32. Huang, S.; Zhou, L.; Li, M.-C.; Wu, Q.; Kojima, Y.; Zhou, D. Preparation and properties of electrospun poly (vinyl pyrrolidone)/cellulose nanocrystal/silver nanoparticle composite fibers. Materials 2016, 9, 523. [CrossRef]

33. Suknuntha, K.; Tantishaiyakul, V.; Vao-Soongnern, V.; Espidel, Y.; Cosgrove, T. Molecular modeling simulation and experimental measurements to characterize chitosan and poly (vinyl pyrrolidone) blend interactions. J. Polym. Sci. Part B Polym. Phys. 2008, 46, 1258-1264. [CrossRef]

34. Roscigno, P.; Asaro, F.; Pellizer, G.; Ortona, O.; Paduano, L. Complex formation between poly (vinylpyrrolidone) and sodium decyl sulfate studied through NMR. Langmuir 2003, 19, 9638-9644. [CrossRef]

35. Zając, A.; Hanuza, J.; Wandas, M.; Dymińska, L. Determination of N-acetylation degree in chitosan using Raman spectroscopy. Spectrochim. Acta Part A Mol. Biomol. Spectrosc. 2015, 134, 114-120. [CrossRef]

36. Fang, N.; Chan, V.; Mao, H.-Q.; Leong, K.W. Interactions of phospholipid bilayer with chitosan: Effect of molecular weight and pH. Biomacromolecules 2001, 2, 1161-1168. [CrossRef]

37. Ryan, C.; Alcock, E.; Buttimer, F.; Schmidt, M.; Clarke, D.; Pemble, M.; Bardosova, M. Synthesis and characterisation of cross-linked chitosan composites functionalised with silver and gold nanoparticles for antimicrobial applications. Sci. Technol. Adv. Mater. 2017, 18, 528-540. [CrossRef] [PubMed]

38. Zhang, K.; Peschel, D.; Helm, J.; Groth, T.; Fischer, S. FT Raman investigation of novel chitosan sulfates exhibiting osteogenic capacity. Carbohydr. Polym. 2011, 83, 60-65. [CrossRef]

39. Kanti, P.; Srigowri, K.; Madhuri, J.; Smitha, B.; Sridhar, S. Dehydration of ethanol through blend membranes of chitosan and sodium alginate by pervaporation. Sep. Purif. Technol. 2004, 40, 259-266. [CrossRef]

40. Mincheva, R.; Manolova, N.; Sabov, R.; Kjurkchiev, G.; Rashkov, I. Hydrogels from chitosan crosslinked with poly (ethylene glycol) diacid as bone regeneration materials. e-Polymers 2004, 4, 643-653. [CrossRef]

41. Orrego, C.; Salgado, N.; Valencia, J.; Giraldo, G.; Giraldo, O.; Cardona, C. Novel chitosan membranes as support for lipases immobilization: Characterization aspects. Carbohydr. Polym. 2010, 79, 9-16. [CrossRef] 
42. Austero, M.S.; Donius, A.E.; Wegst, U.G.; Schauer, C.L. New crosslinkers for electrospun chitosan fibre mats. I. Chemical analysis. J. R. Soc. Interface 2012, 9, 2551-2562. [CrossRef] [PubMed]

43. Schiffman, J.D.; Schauer, C.L. Cross-linking chitosan nanofibers. Biomacromolecules 2007, 8, 594-601. [CrossRef]

44. Chen, J.-P.; Chang, G.-Y.; Chen, J.-K. Electrospun collagen/chitosan nanofibrous membrane as wound dressing. Colloids Surf. A Physicochem. Eng. Asp. 2008, 313, 183-188. [CrossRef]

45. Zhao, R.; Li, X.; Sun, B.; Zhang, Y.; Zhang, D.; Tang, Z.; Chen, X.; Wang, C. Electrospun chitosan/sericin composite nanofibers with antibacterial property as potential wound dressings. Int. J. Biol. Macromol. 2014, 68, 92-97. [CrossRef] [PubMed]

46. Labuschagne, P.W.; John, M.J.; Sadiku, R.E. Investigation of the degree of homogeneity and hydrogen bonding in PEG/PVP blends prepared in supercritical $\mathrm{CO}_{2}$ : Comparison with ethanol-cast blends and physical mixtures. J. Supercrit. Fluids 2010, 54, 81-88. [CrossRef]

47. Zhu, L.-F.; Zheng, Y.; Fan, J.; Yao, Y.; Ahmad, Z.; Chang, M.-W. A novel core-shell nanofiber drug delivery system intended for the synergistic treatment of melanoma. Eur. J. Pharm. Sci. 2019, 137, 105002. [CrossRef] [PubMed]

48. Sarhan, W.A.; Azzazy, H.M. High concentration honey chitosan electrospun nanofibers: Biocompatibility and antibacterial effects. Carbohydr. Polym. 2015, 122, 135-143. [CrossRef]

49. Jouybari, M.H.; Hosseini, S.; Mahboobnia, K.; Boloursaz, L.A.; Moradi, M.; Irani, M. Simultaneous controlled release of 5-FU, DOX and PTX from chitosan/PLA/5-FU/g-C3N4-DOX/g-C3N4-PTX triaxial nanofibers for breast cancer treatment in vitro. Colloids Surf. B Biointerfaces 2019, 179, 495-504. [CrossRef]

50. Mccarron, P.A.; Woolfson, A.D.; Keating, S.M. Sustained release of 5-fluorouracil from polymeric nanoparticles. J. Pharm. Pharmacol. 2000, 52, 1451-1459. [CrossRef]

51. Cheng, M.; Gao, X.; Wang, Y.; Chen, H.; He, B.; Xu, H.; Li, Y.; Han, J.; Zhang, Z. Synthesis of glycyrrhetinic acid-modified chitosan 5-fluorouracil nanoparticles and its inhibition of liver cancer characteristics in vitro and in vivo. Mar. Drugs 2013, 11, 3517-3536. [CrossRef]

52. Smith, T.; Affram, K.; Bulumko, E.; Agyare, E. Evaluation of in-vitro cytotoxic effect of 5-FU loaded-chitosan nanoparticles against spheroid models. J. Nat. Sci. 2018, 4, e535. [PubMed]

53. Rose, P.A.; Praseetha, P.; Bhagat, M.; Alexander, P.; Abdeen, S.; Chavali, M. Drug embedded PVP coated magnetic nanoparticles for targeted killing of breast cancer cells. Technol. Cancer Res. Treat. 2013, 12, 463-472. [CrossRef]

54. Rejinold, N.S.; Chennazhi, K.; Nair, S.; Tamura, H.; Jayakumar, R. Biodegradable and thermo-sensitive chitosan-g-poly (Nvinylcaprolactam) nanoparticles as a 5-fluorouracil carrier. Carbohydr. Polym. 2011, 83, 776-786. [CrossRef]

55. Szalai, B.; Subramanian, V.; Holland, C.H.; Alföldi, R.; Puskás, L.G.; Saez-Rodriguez, J. Signatures of cell death and proliferation in perturbation transcriptomics data-from confounding factor to effective prediction. Nucleic Acids Res. 2019, 47, 10010-10026. [CrossRef] [PubMed]

56. Hu, J.; Zeng, F.; Wei, J.; Chen, Y.; Chen, Y. Novel controlled drug delivery system for multiple drugs based on electrospun nanofibers containing nanomicelles. J. Biomater. Sci. Polym. Ed. 2014, 25, 257-268. [CrossRef] [PubMed]

57. Mano, J.; Silva, G.; Azevedo, H.S.; Malafaya, P.; Sousa, R.; Silva, S.S.; Boesel, L.; Oliveira, J.M.; Santos, T.; Marques, A. Natural origin biodegradable systems in tissue engineering and regenerative medicine: Present status and some moving trends. J. R. Soc. Interface 2007, 4, 999-1030. [CrossRef] 